\title{
Efek asupan vitamin D terhadap tekanan darah sistolik tikus putih (Rattus norvegicus)
}

\author{
The effect of vitamin D intake on systolic blood pressure of Rattus norvegicus
}

Dessy Hermawan ${ }^{1}$, Sri Kadarsih'², Sunarti ${ }^{3}$, Indwiani Astuti', Zaenal Arifin Nang Agus ${ }^{3}$

\begin{abstract}
Background: Hypertension still became potential life threatening disease for human life. The prevalence of hypertension was high and tends to increase. Previous study suggested that there was a linier rise in blood pressure at increasing distances from the equator. More recent study indicated that vitamin $D$ insufficiency may be associated with elevated blood pressure.

Objective: To investigate the effect of vitamin D intake on blood pressure.

Method: This was an experimental study with pre-post test group design. The subjects were 20 male Rattus norvegicus aged 8 weeks. Subjects were divided into 5 groups and each groups received treatment as follow: lived in dark cage and consumed vitamin $D$ free diet for 1 - 13 days, then moved to normal cage (dark-light period) and given vitamin $D$ per-oral of $0.25 \mu \mathrm{g} / \mathrm{kg}$ BW for 1 - 5 days. Data of systolic blood pressure was collected and analyzed with paired t test.

Result: The absence of vitamin $D$ in diet caused a significant increase in systolic blood pressure $(p=0.01)$ after 7 days of treatment in dark cage. While oral vitamin D supplementation of $0.25 \mu \mathrm{g} / \mathrm{kg} \mathrm{BW}$ caused a significant decline of systolic blood pressure since the first day of vitamin $D$ supplementation and the result appeared stronger after 4 days of treatment $(p=0.001)$.
\end{abstract}

Conclusion: Vitamin D intake had a strong influence on systolic blood pressure

KEY WORDS: hypertension, vitamin D, systolic blood pressure

\begin{abstract}
ABSTRAK
Latar belakang: Hipertensi masih merupakan penyakit yang mengancam kehidupan manusia. Angka kejadian hipertensi di Indonesia masih tinggi dan cenderung meningkat. Penelitian tentang hipertensi melaporkan bahwa ada korelasi antara jarak dari khatulistiwa dengan tekanan darah, semakin jauh tempat tinggal dari khatulistiwa maka akan cenderung terjadi peningkatan tekanan darah. Hal ini karena tubuh kekurangan kadar vitamin D akibat kekurangan paparan sinar matahari.

Tujuan: Mempelajari pengaruh penurunan dan peningkatan asupan vitamin D terhadap tekanan darah.

Metode: Rancangan penelitian ini adalah eksperimen laboratorik dengan pre-post test group design. Subjek penelitian ini adalah 20 ekor tikus putih (Rattus norvegicus) jantan usia 2 bulan. Subjek dibagi menjadi lima kelompok perlakuan yang masing-masing mendapat perlakuan yaitu diletakkan dalam kandang gelap dan diberi pakan tanpa vitamin $D$ selama 1 - 13 hari, kemudian subjek diletakkan dalam kandang terang dan diberi asupan vitamin $D$ sebesar 0,25 $\mu \mathrm{g} / \mathrm{kg}$ BB selama 1 - 5 hari. Data berupa tekanan darah sistolik sebelum dan sesudah perlakuan dikumpulkan dan dianalisis dengan menggunakan uji t berpasangan.

Hasil: Penghilangan asupan vitamin D dengan meletakkan di dalam kandang gelap dan diberi pakan bebas vitamin $D$ menyebabkan terjadinya peningkatan tekanan darah sistolik secara bermakna. Peningkatan tekanan darah sistolik akan sangat bermakna $(p=0,01)$ setelah 7 hari penghilangan asupan vitamin $D$. Pemberian kembali asupan vitamin $D$ $0,25 \mu \mathrm{g} / \mathrm{kg}$ BB menyebabkan terjadinya penurunan tekanan darah sejak hari pertama pemberian. Namun, penurunan tekanan darah sistolik akan sangat bermakna $(p=0,001)$ setelah hari keempat pemberian asupan vitamin $D$.

Kesimpulan: Asupan vitamin D sangat berpengaruh terhadap tekanan darah sistolik hewan coba.
\end{abstract}

KATA KUNCI: hipertensi, vitamin D, tekanan darah sistolik

\section{PENDAHULUAN}

Hipertensi merupakan penyakit yang diderita $30 \%$ dari populasi orang dewasa di Amerika dan angka kejadiannya cenderung mengalami peningkatan (1). Di Indonesia pada tahun 2007 dilaporkan prevalensi hipertensi sebesar 17$22 \%$ dan pada tahun 2009 meningkat menjadi 32,2\% (2). Hipertensi merupakan penyakit yang sangat berbahaya, jika
${ }^{1}$ Korespondensi: Fakultas Kesehatan Masyarakat Universitas Malahayati, Jl. Pramuka No. 27, Kemiling, Bandar Lampung, Telp (0721) 271114, e-mail: hermawan_dessy@yahoo.co.id

2 Bagian Fisiologi, Fakultas Kedokteran Universitas Gadjah Mada, Jl. Farmako, Sekip Utara, Yogyakarta 55281

${ }^{3}$ Bagian Biokimia, Fakultas Kedokteran Universitas Gadjah Mada, Jl. Farmako, Sekip Utara, Yogyakarta 55281, e-mail: nartyr@ugm.ac.id

${ }^{4}$ Bagian Farmakologi, Fakultas Kedokteran Universitas Gadjah Mada, JI. Farmako, Sekip Utara, Yogyakarta 55281 
tidak ditangani dengan cepat dan tepat dapat menimbulkan komplikasi berupa penyakit kardiovaskuler, jantung koroner, gagal jantung, gagal ginjal, kelahiran prematur hingga kematian. Bahkan sampai saat ini penyebab tersering hipertensi (90\%) belum diketahui dengan pasti (3). Namun, banyak penderita yang tidak menyadari bahwa mereka menderita hipertensi. Data menunjukkan bahwa di Amerika terdapat $9,2 \%$ orang terdiagnosis hipertensi ketika datang ke dokter atau tenaga kesehatan tanpa adanya keluhan hipertensi (4).

Kondisi ini membuat hipertensi menjadi penyakit yang ditakuti dan diusahakan untuk dihindari oleh masyarakat. Di sisi lain, kondisi ini menarik bagi para peneliti di bidang kesehatan untuk meneliti lebih jauh penyebab hipertensi. Penelitian akhir-akhir ini melaporkan bahwa semakin jauh manusia tinggal dari garis khatulistiwa maka semakin cenderung mengalami peningkatan tekanan darah (5). Kondisi ini diduga karena semakin jauh dari khatulistiwa maka tubuh akan kekurangan vitamin D. Hal ini terjadi akibat tubuh kekurangan paparan matahari (ultraviolet) sehingga kulit tidak mampu melakukan biosintesis provitamin $D$ menjadi vitamin D (6). Penelitian tersebut didukung oleh sejumlah penelitian sejenis yang membuktikan bahwa ditemukan kadar vitamin $D$ yang rendah pada penderita hipertensi (7-9). Bahkan penelitian lain melaporkan bahwa pemberian vitamin $D$ dapat menurunkan produksi renin dengan menekan langsung produksi renin di ginjal, hanya saja mekanismenya belum dapat diterangkan dengan pasti. Diduga vitamin $D$ langsung menekan gen yang mengode renin (10).

Berdasarkan hasil penelitian di atas timbul banyak pertanyaan. Jika benar bahwa semakin jauh tempat tinggal dari khatulistiwa tekanan darah akan cenderung meningkat karena kadar vitamin $\mathrm{D}$ dalam darah rendah, maka seharusnya angka kejadian hipertensi di negara tropis seperti Indonesia sangatlah rendah. Hal ini karena negara tropis mendapat paparan matahari sepanjang tahun sehingga kemungkinan kekurangan biosintesis vitamin $D$ sangat rendah. Namun ternyata justru sebaliknya, angka kejadian hipertensi masih sangat tinggi di Indonesia. Kondisi ini mendorong peneliti untuk menyelidiki lebih jauh apakah ada pengaruh asupan vitamin D terhadap tekanan darah.

\section{BAHAN DAN METODE}

Penelitian ini adalah penelitian eksperimen laboratorik sederhana dengan rancangan pre post test group design yang mencoba mempelajari pengaruh pemberian dan penghilangan vitamin $D$ terhadap tekanan darah sistolik hewan coba. Subjek dalam penelitian ini adalah 20 ekor tikus putih (Rattus norvegicus) jantan usia 8 minggu yang diperoleh dari Laboratorium Penelitian dan Pengujian Terpadu Universitas Gadjah Mada (LPPT UGM) Yogyakarta.
Tabel 1. Perlakuan untuk masing-masing kelompok

\begin{tabular}{|c|c|c|}
\hline Kelompok & $\begin{array}{l}\text { Penghilangan } \\
\text { asupan Vit D }\end{array}$ & $\begin{array}{c}\text { Pemberian asupan } \\
\text { kembali Vit } D\end{array}$ \\
\hline K1 & $\begin{array}{l}\text { Diletakkan dalam } \\
\text { kandang gelap \& } \\
\text { diberi pakan tanpa } \\
\text { vitamin D selama } \\
1 \text { hari }\end{array}$ & $\begin{array}{l}\text { Diletakkan kembali dalam } \\
\text { kandang terang, diberi } \\
\text { pakan standar \& } 0,25 \mu \mathrm{g} / \\
\text { kg/hari asupan vitamin } \mathrm{D} \text { per } \\
\text { oral selama } 1 \text { hari }\end{array}$ \\
\hline $\mathrm{K} 2$ & $\begin{array}{l}\text { Diletakkan dalam } \\
\text { kandang gelap \& } \\
\text { diberi pakan tanpa } \\
\text { vitamin D selama } \\
4 \text { hari }\end{array}$ & $\begin{array}{l}\text { Diletakkan kembali dalam } \\
\text { kandang terang, diberi } \\
\text { pakan standar \& } 0,25 \mu \mathrm{g} / \\
\mathrm{kg} / \text { hari asupan vitamin } \mathrm{D} \text { per } \\
\text { oral selama } 2 \text { hari }\end{array}$ \\
\hline K3 & $\begin{array}{l}\text { Diletakkan dalam } \\
\text { kandang gelap \& } \\
\text { diberi pakan tanpa } \\
\text { vitamin D selama } \\
7 \text { hari }\end{array}$ & $\begin{array}{l}\text { Diletakkan kembali dalam } \\
\text { kandang terang, diberi } \\
\text { pakan standar \& } 0,25 \mu \mathrm{g} / \\
\text { kg/hari asupan vitamin D per } \\
\text { oral selama } 3 \text { hari }\end{array}$ \\
\hline K4 & $\begin{array}{l}\text { Diletakkan dalam } \\
\text { kandang gelap \& } \\
\text { diberi pakan tanpa } \\
\text { vitamin D selama } \\
10 \text { hari }\end{array}$ & $\begin{array}{l}\text { Diletakkan kembali dalam } \\
\text { kandang terang, diberi } \\
\text { pakan standar \& } 0,25 \mu \mathrm{g} / \\
\mathrm{kg} / \text { hari asupan vitamin } \mathrm{D} \text { per } \\
\text { oral selama } 4 \text { hari }\end{array}$ \\
\hline K5 & $\begin{array}{l}\text { Diletakkan dalam } \\
\text { kandang gelap \& } \\
\text { diberi pakan tanpa } \\
\text { vitamin D selama } \\
13 \text { hari }\end{array}$ & $\begin{array}{l}\text { Diletakkan kembali dalam } \\
\text { kandang terang, diberi } \\
\text { pakan standar \& } 0,25 \mu \mathrm{g} / \\
\mathrm{kg} / \text { hari asupan vitamin } \mathrm{D} \text { per } \\
\text { oral selama } 5 \text { hari }\end{array}$ \\
\hline
\end{tabular}

Pemeliharaan dan perlakuan serta pengukuran tekanan darah sistolik hewan coba dilakukan di laboratorium hewan coba Pusat Antar Universitas (PAU) UGM Yogyakarta. Subjek dibagi menjadi 5 kelompok perlakukan (K1 - K5) yang masing-masing akan mengalami perlakuan berupa penghilangan asupan vitamin $\mathrm{D}$ dan pemberian kembali asupan vitamin D (Tabel 1).

Untuk mempelajari pengaruh penghilangan asupan vitamin $\mathrm{D}$ terhadap penurunan tekanan darah sistolik maka tikus diberi perlakuan dengan meletakkan subjek di dalam kandang gelap dan memberi pakan tanpa vitamin D selama satu hari untuk $\mathrm{K} 1$, empat hari untuk $\mathrm{K} 2$, tujuh hari untuk K3, 10 hari untuk K4, dan 13 hari untuk K5. Lama penghilangan vitamin $\mathrm{D}$ diberi jarak dengan kelipatan 3 (tiga) hari karena belum ada data awal tentang berapa lama tikus akan mengalami peningkatan tekanan darah jika diberi perlakuan berupa penghilangan asupan vitamin D.

Pada hari-hari tersebut (hari ke 1, 4, 7, 10, dan 13) subjek diukur tekanan darah sistoliknya dengan menggunakan alat pengukur tekanan darah yang ada di laboratorium PAU UGM. Arteri yang digunakan untuk pengukuran tekanan darah adalah arteri ekor tikus dan hanya tekanan darah sistolik saja yang dapat terbaca oleh alat tersebut. Kemudian untuk mempelajari pengaruh pemberian kembali asupan vitamin $\mathrm{D}$ terhadap penurunan tekanan darah sistolik, subjek dipindahkan kembali di dalam kandang terang dan diberi pakan standar American Institute of Nutrition-93 (AIN 93) serta diberikan tambahan 
asupan vitamin $D$ per oral sebanyak $0,25 \mu \mathrm{g} / \mathrm{kg}$ berat badan (BB). Perlakuan ini diberikan selama satu hari untuk $\mathrm{K} 1$, dua hari untuk $\mathrm{K} 2$, tiga hari untuk $\mathrm{K} 3$, empat hari untuk K4, dan lima hari untuk K5. Pengukuran kembali tekanan darah sistolik dilakukan pada hari tersebut (hari ke 1, 2, 3 , 4, dan 5). Data yang terkumpul berupa data tekanan darah sistolik selama beberapa hari dianalisis dengan menggunakan uji t berpasangan untuk melihat apakah ada perbedaan tekanan darah sistolik sebelum dan setelah penghilangan asupan vitamin $\mathrm{D}$ serta saat diberi kembali asupan vitamin D.

\section{HASIL}

Pada Gambar 1 tampak adanya peningkatan tekanan darah sistolik setelah meletakkan hewan coba di kandang gelap dan tanpa asupan vitamin D selama beberapa hari. Gambar 1 menunjukkan adanya peningkatan tekanan darah sistolik dari $88 \mathrm{mmHg}$ pada hari pertama penghilangan asupan menjadi $130 \mathrm{mmHg}$ pada hari ke 13 penghilangan asupan vitamin $D$.

Tabel 2. Hasil uji t berpasangan rata-rata peningkatan tekanan darah sistolik pre-post penghilangan asupan vitamin D

\begin{tabular}{ccccc}
\hline Pasangan & \multirow{2}{*}{ Rerata } & \multicolumn{2}{c}{$95 \% \mathrm{Cl}$} & \multirow{2}{*}{$\mathbf{~}$} \\
\cline { 3 - 4 } & & Lower & Upper & \\
\hline $\begin{array}{c}\text { Pre-post K1 } \\
\text { (1 hari tanpa vit D) } \\
\quad \text { Pre-post K2 }\end{array}$ & $-1,50$ & $-6,78$ & 3,78 & 0,432 \\
$\begin{array}{c}\text { (4 hari tanpa vit D) } \\
\quad \text { Pre-post K3 }\end{array}$ & $-10,50$ & $-18,97$ & $-2,03$ & $0,029^{*}$ \\
$\begin{array}{c}\text { (7 hari tanpa vit D) } \\
\quad \text { Pre-post K4 }\end{array}$ & $-41,75$ & $-52,09$ & $-31,40$ & $0,001^{* *}$ \\
$\begin{array}{c}\text { (10 hari tanpa vit D) } \\
\quad \begin{array}{c}\text { Pre-post K5 } \\
\text { (13 hari tanpa vit D) }\end{array}\end{array}$ & $-47,50$ & $-57,26$ & $-37,73$ & $0,001^{* *}$ \\
\hline
\end{tabular}

* Signifikan $(p<0,05)$

** Signifikan $(p<0,01)$

Tabel 3. Hasil uji t berpasangan rata-rata penurunan tekanan darah sistolik pre-post setelah pemberian asupan per oral vitamin D $0,25 \mu \mathrm{g} / \mathrm{kg} B B$

\begin{tabular}{|c|c|c|c|c|}
\hline \multirow{2}{*}{ Pasangan kelompok } & \multirow{2}{*}{ Rerata } & \multicolumn{2}{|c|}{$95 \% \mathrm{Cl}$} & \multirow{2}{*}{ p } \\
\hline & & Lower & Upper & \\
\hline $\begin{array}{c}\text { Pre-post K1 } \\
\text { (1 hari pemberian vit } \mathrm{D})\end{array}$ & 7,50 & 3,29 & 11,09 & $0,011^{*}$ \\
\hline $\begin{array}{c}\text { Pre-post K2 } \\
\text { (2 hari pemberian vit } \mathrm{D})\end{array}$ & 16,00 & 6,19 & 25,81 & $0,014^{*}$ \\
\hline $\begin{array}{c}\text { Pre-post K3 } \\
\text { (3 hari pemberian vit } \mathrm{D})\end{array}$ & 25,25 & 1,10 & 49,39 & $0,045^{*}$ \\
\hline $\begin{array}{c}\text { Pre-post K4 } \\
\text { (4 hari pemberian vit } \mathrm{D})\end{array}$ & 30,00 & 23,25 & 36,75 & $0,001^{* *}$ \\
\hline $\begin{array}{c}\text { Pre-post K5 } \\
\text { (5 hari pemberian vit D) }\end{array}$ & 39,50 & 35,49 & 43,50 & $0,000^{* *}$ \\
\hline
\end{tabular}

* Signifikan 0,05

** Signifikan 0,01

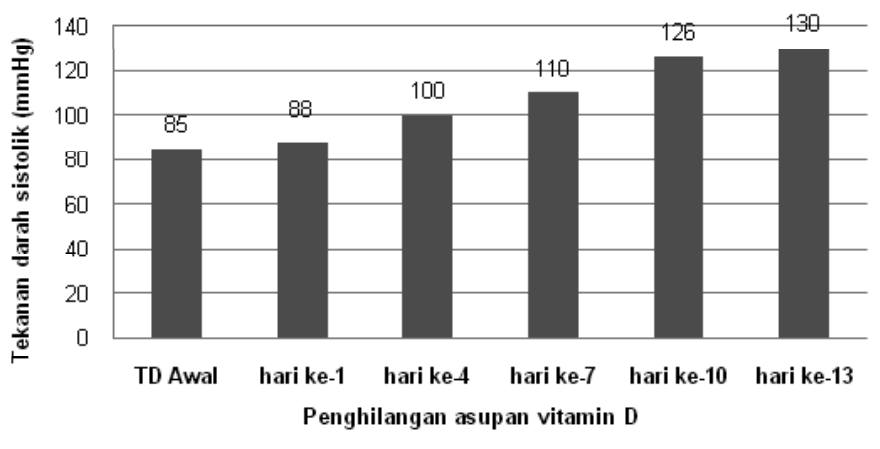

Gambar 1. Rata-rata peningkatan tekanan darah sistolik setelah penghilangan asupan vitamin $D$

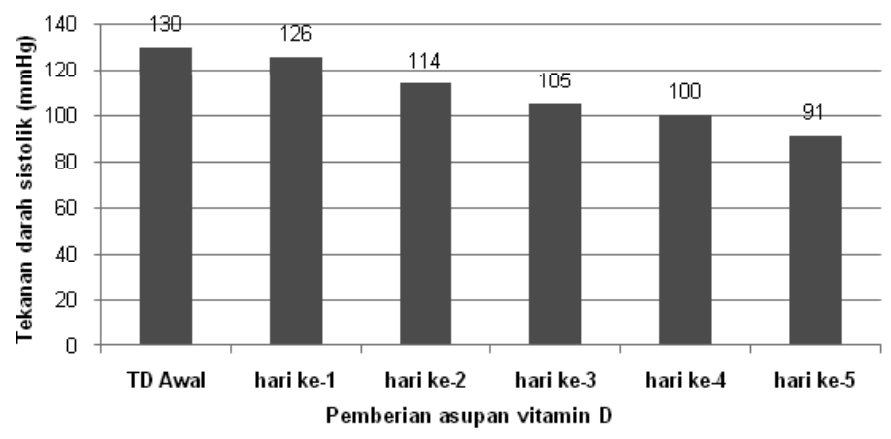

Gambar 2. Rata-rata penurunan tekanan darah sistolik setelah pemberian asupan vitamin D

Tabel 2 menunjukkan bahwa perlakuan penghilangan asupan vitamin $\mathrm{D}$ dan pemberian pakan tanpa vitamin $\mathrm{D}$ sudah mampu meningkatkan tekanan darah sistolik secara bermakna $(p=0,029)$ mulai pada hari penghilangan keempat (K2). Namun demikian, peningkatan tekanan darah sistolik akan sangat bermakna $(p=0,01)$ mulai pada penghilangan hari ketujuh (K3).

Pada Gambar 2 tampak adanya penurunan tekanan darah setelah hewan coba diletakkan kembali di kandang terang dan diberi asupan vitamin $D$ sebanyak 0,25 $\mu \mathrm{g} /$ kg BB secara per oral. Semakin lama pemberian vitamin $\mathrm{D}$, tekanan darah sistolik semakin menurun. Pada hari pertama pemberian kembali asupan vitamin $D$, tekanan darah sistoliknya sebesar $126 \mathrm{mmHg}$ dan turun menjadi $91 \mathrm{mmHg}$ pada hari kelima. Berdasarkan Tabel 3 tampak jelas adanya penurunan tekanan darah secara bermakna setelah pemberian per oral vitamin D sebanyak 0,25 $\mu \mathrm{g} /$ $\mathrm{kg} \mathrm{BB}$, hanya saja masih tampak adanya fluktuasi nilai $\mathrm{p}$ namun mulai tampak stabil dan makin bermakna $(p=0,001)$ setelah pemberian asupan vitamin D selama 4 hari (K4).

\section{BAHASAN}

Pengaruh penghilangan (penurunan) asupan vitamin D

Hasil penelitian menunjukkan adanya peningkatan tekanan darah sistolik setelah diberi perlakuan berupa penghilangan asupan vitamin $D$ dengan cara tikus diberi pakan tanpa vitamin $\mathrm{D}$ dan diletakkan dalam 


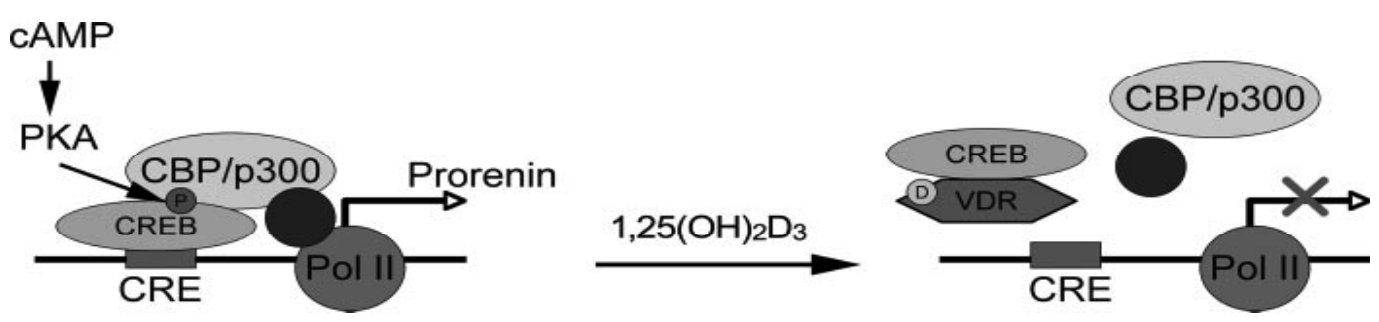

Gambar 3. Mekanisme vitamin $D$ sebagai pengatur negatif gen renin

(Sumber: Yuan W, et al. J Biol Chem 2007;282:29821-30)

kandang gelap. Peningkatan tekanan darah sistolik secara bermakna akan sangat tampak pada hari ketujuh penghilangan asupan vitamin $\mathrm{D}$.

Data tersebut sesuai dengan hasil penelitian di Amerika Serikat (5) yang menyatakan bahwa kadar vitamin D dalam darah berkorelasi dengan tekanan darah. Semakin jauh orang tinggal dari khatulistiwa, maka semakin tinggi tekanan darahnya karena kadar vitamin D-nya rendah. Hal ini disebabkan tubuh kekurangan paparan sinar matahari sehingga tidak mampu secara adekuat mengubah pro vitamin $D$ menjadi vitamin D. Kondisi ini didukung oleh penelitian yang menyatakan bahwa sebagian besar wanita dewasa di Finlandia mengalami kekurangan vitamin $D$ di dalam darahnya selama musim dingin akibat kekurangan paparan sinar matahari (11). Hal ini menunjukan bahwa pada musim dingin, vitamin $D$ dari makanan saja kemungkinan tidak cukup untuk mempertahankan kadar vitamin $\mathrm{D}$ dalam darah sehingga tekanan darah sistolik dapat meningkat. Namun, belum ada data yang menunjukkan bahwa pemberian tambahan vitamin $D$ secara oral pada musim dingin mampu mempertahankan laju peningkatan tekanan darah.

Hasil penelitian ini juga sejalan dengan hasil penelitian (12) yang menunjukkan bahwa ada hubungan antara tekanan darah dan kadar vitamin $D$ pada orangorang kulit putih di Amerika dan ditemukannya kadar vitamin $D$ darah yang rendah pada penderita hipertensi (7-9). Kondisi ini disebabkan vitamin $D$ turut berperan dalam penghambatan transkripsi gen renin yaitu jika kadar vitamin $D$ dalam darah rendah maka tidak ada yang menghambat transkripsi gen renin sehingga renin diproduksi (10).

Mekanisme penghambatan vitamin D dalam transkripsi gen renin secara jelas diterangkan pada Gambar $3(6,11)$. Mekanisme transkripsi gen renin melalui aktivasi Protein Kinase $A$ (PKA) oleh cyclic AMP (cAMP) seperti pada Gambar 3, akan terganggu jika ada stimulasi dari vitamin $D$ karena ikatan antara vitamin $D$ pada vitamin $D$ receptor (VDR) akan mampu berikatan dengan cAMP Response Element Binding (CREB). Akibatnya CREB tidak berikatan dengan cAMP response element (CRE) sehingga aktivasi cAMP Binding Protein/Protein 300 (CBP/p300) tidak terjadi dan transkripsi gen renin tidak terjadi pula. Oleh sebab itu, vitamin D dikenal sebagai pengatur negatif untuk gen renin $(6,13)$. Sebaliknya, jika kadar vitamin D dalam darah rendah maka tidak ada yang menghambat produksi renin sehingga renin diproduksi dan disekresikan. Padahal jika renin disekresikan oleh sel juktaglomerular ginjal, akan segera memotong angiotensinogen menjadi angiotensin I. Dengan angiotensin converting enzyme, angiotensin I akan menjadi angiotensin II. Adanya angiotensin II akan menyebabkan disekresikannya aldosteron sehingga tubuh akan meretensi air dan natrium. Akibat adanya retensi air dan natrium adalah meningkatnya volume cairan ekstraseluler (CES) sehingga hasil akhirnya adalah peningkatan tekanan darah (14-16).

\section{Pengaruh pemberian (peningkatan) asupan vitamin D}

Hasil penelitian menunjukkan adanya penurunan tekanan darah sistolik setelah tikus diberi asupan vitamin D per oral sebanyak $0,25 \mu \mathrm{g} / \mathrm{kg}$ BB per hari. Penurunan tekanan darah sistolik sudah mulai tampak sejak hari pertama pemberian dan sangat signifikan $(p=0,001)$ mulai pada hari keempat pemberian vitamin $\mathrm{D}$.

Hasil penelitian ini sejalan dengan penelitian di Jepang (17) yang memberi terapi vitamin D selama 2 minggu dan menemukan adanya penurunan aktivitas renin dan tekanan darah baik sistolik maupun diastolik. Hasil penelitian ini didukung pula oleh penelitian yang menyatakan bahwa asupan tinggi vitamin $D$ berhubungan dengan penurunan risiko menderita penyakit kardiovaskuler pada laki-laki tetapi tidak pada perempuan di Amerika (18). Hasil penelitian ini menunjukkan bahwa ada potensi pemberian tambahan vitamin D per oral sebagai bahan alternatif untuk menurunkan tekanan darah. Terutama pada orang-orang yang mengalami peningkatan tekanan darah akibat kekurangan biosintesis vitamin $\mathrm{D}$ pada musim dingin. Meskipun demikian, data pra klinik awal ini masih perlu diuji lebih lanjut untuk dapat meyakinkan bahwa tambahan vitamin D secara oral mampu menurunkan tekanan darah sistolik pada manusia. Jika kita membahas secara cermat tentang mekanisme produksi dan sekresi renin di sel macula densa dan juktaglomerular ginjal, sebenarnya melibatkan banyak komponen yang terlibat di dalamnya, secara jelas terlihat pada Gambar 4. 


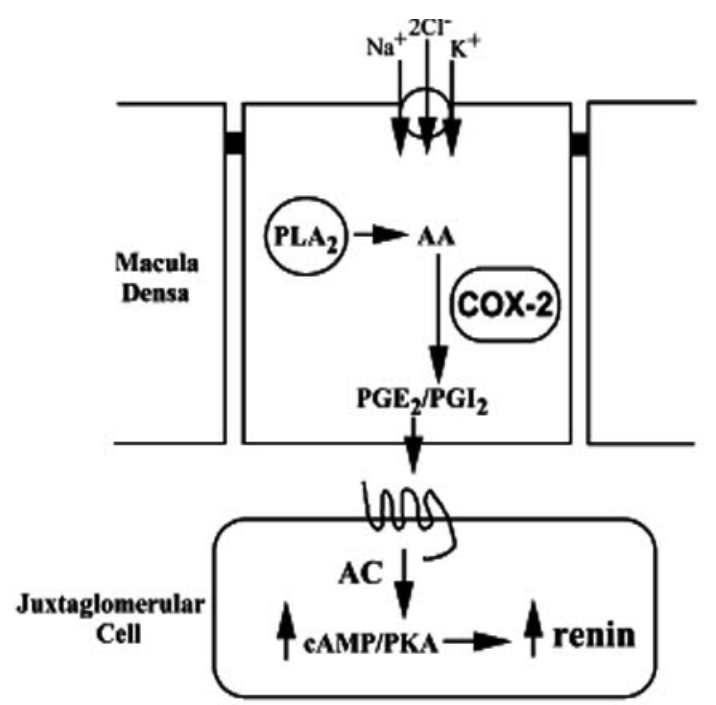

Gambar 4. Mekanisme sekresi renin di sistem renin angiotensin-aldosteron

(Sumber: Hall JE. Guyton and hall review physiology, Sherwood L. Human physiology from cell to systems)

Pada Gambar 4 tampak peranan penting Cyclooxygenase-2 (COX-2) dalam pelepasan renin. Adanya COX-2 yang menyebabkan pengubaha $\mathrm{n}$ asam arakidonat menjadi prostaglandin sehingga proses selanjutnya yaitu pelepasan renin di sel juktaglomerular dapat terjadi $(19,20)$. Setelah prostaglandin dibentuk di sel macula densa ginjal, akan segera ditangkap oleh reseptor prostaglandin di sel juxtaglomerular. Adanya reaksi antara prostaglandin dan reseptornya menyebabkan teraktivasinya adenylate cyclase (AC), akibatnya cAMP dan protein kinase $A$ teraktivasi pula dan mengalami peningkatan produksi. Hasil akhirnya adalah peningkatan produksi renin $(14,15)$. Namun demikian, informasi ini masih menimbulkan banyak pertanyaan, diantaranya bagaimana hubungan antara COX-2, prostaglandin, dan CAMP dengan vitamin D. Seperti kita ketahui bahwa Cyclooxygenase-2 (COX-2), prostaglandin, dan cAMP merupakan komponen yang sangat penting dalam mekanisme sekresi renin.

\section{SIMPULAN DAN SARAN}

Penghilangan asupan vitamin D selama tujuh hari mampu meningkatan tekanan darah sistolik secara signifikan dan sebaliknya pemberian asupan vitamin $D$ per oral sebanyak $0,25 \mu \mathrm{g}$ selama empat hari mampu menurunkan tekanan darah sistolik hewan coba secara signifikan. Namun, masih diperlukan penelitian lebih dalam tentang pengaruh vitamin $\mathrm{D}$ dalam mekanisme produksi renin yang berkaitan dengan COX-2, prostaglandin, dan cAMP agar diperoleh gambaran yang lengkap tentang mekanisme penghambatan produksi dan sekresi renin oleh vitamin $\mathrm{D}$.

\section{RUJUKAN}

1. Ong KL, Cheung BM, Man YB, Lau CP, Lam KS. Prevalence awareness, treatment, and control of hypertension among US adults 1999-2004. Hypertension 2007;49:69-75.

2. Rahajeng $E$, Tuminah S. Prevalensi hipertensi dan deternimannya di Indonesia. Majalah Kedokteran Indonesia 2009;59(12):580-7.

3. Smeltzer SC, Bare BG. Textbook of medical-surgical nursing. Jakarta: Penerbit Buku Kedokteran EGC; 2002.

4. Ma J, Stafford RS. Screening, treatment and control of hypertension in US private physician officer 20032004. Hypertension 2008;51(5):1275-81.

5. Rostand SG. Ultraviolet light may contribute to geographic and racial blood pressure differences. Hypertension 1997;30(2 Pt 1):150-6.

6. Li YC. Vitamin $D$ regulation of the renin angiotensin system: mechanism and implication. [series online] 2007 [cited 2011 July 20]. Available from: URL:http:// www.unimet.edu/cin2007.

7. Forman JP, Giovannucci E, Holmes MD, Ferrari HAB, Tworoger SS, Willett WC, Curhan GC. Plasma 25-hydroxyvitamin $D$ levels and risk of incident hypertension. Hypertension 2007;49(5):1063-9.

8. Martini LA, Wood RJ. Vitamin D and blood pressure connection: update on epidemiologic, clinical, and mechanistic evidence. Nutr Rev 2008;66(5):291-7.

9. Heaney RP. Vitamin D in health and disease. Clin J Am Soc Nephrol 2008;3(5):1535-41.

10. Li YC, Kong J, Wei M, Chen ZF, Liu SQ, Cao LP. 1,25 -Dihydroxyvitamin $\mathrm{D}(3)$ is a negative endocrine regulator of the renin-angitensin system. J Clin Invest 2002;110(2):229-38.

11. Outila TA, Karkkainen MUM, Lamberg-Allardt CJE. Vitamin D status affect serum parathyroid hormone concentration during winter in female adolescents: associations with forearm bone mineral density. Am J Clin Nutr 2001:74(2):206-10.

12. Judd SE, Nanes MS, Ziegler TR, Wilson PWF, Tangpricha V. Optimal vitamin D status the age-associated increase in systolic blood pressure in white Americans: result the third national health and nutrition examination survey. Am J Clin Nutr 2008;87(1):136-41.

13. Yuan W, Pan W, Kong J, Zheng W, Szeto FL, Wong KE, Cohen R, Klopot A, Zhang Z, Li YC. 1,25-dihydroxyvitamin D3 suppresses renin gene transcription by blocking the activity of the cyclic AMP response element in the renin gene promoter. J Biol Chem 2007;282(41):29281-30.

14. Barret KE, Brooks H, Baitano S, Barman SM. Ganong's review of medical physiology 23 edition. USA: Mc-Graw Hill-Lange; 2010. 
15. Hall JE. Guyton and hall review physiology. Philadelphia: Sauders-Elsevier; 2006.

16. Sherwood L. Human physiology from cell to systems 7 edition. Canada: Yolanda Cassio; 2010.

17. Kimura Y, Kawamura M, Owada M, Oshima T, Murooka M, Fujiwara T, Hiramori K. Effectiveness of 1,25-dehydroxyvitamin $\mathrm{D}$ supplementation on blood pressure reduction in a pseudohypoparathyroidism patient with high renin activity. Intern Med 1999;38(1):31-5.
18. Sun Q, Shi L, Rimm EB, Giovannucci EL, Hu FB, Manson JE, Rexrode KM. Vitamin D intake and risk of cardiovascular disease in US men and women. Am J Clin Nutr 2011;94(2):534-42.

19. Harris RC, Breyer MD. Physiological regulation of cyclooxygenase-2 in the kidney. Am J Physiol Renal Physiol 2001;281(1):F1-11.

20. Bell PD, Komlosi P, Zhang ZR. ATP as a mediator of macula densa cell signalling. Purinergic Signal 2009;5(4):461-71. 